\title{
PNNL-17850
}

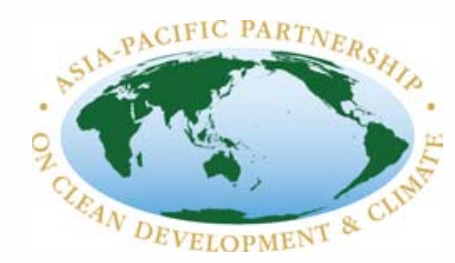

\section{Country Report on Building Energy Codes in Australia}

\author{
B Shui \\ M Evans \\ S Somasundaram
}

April 2009

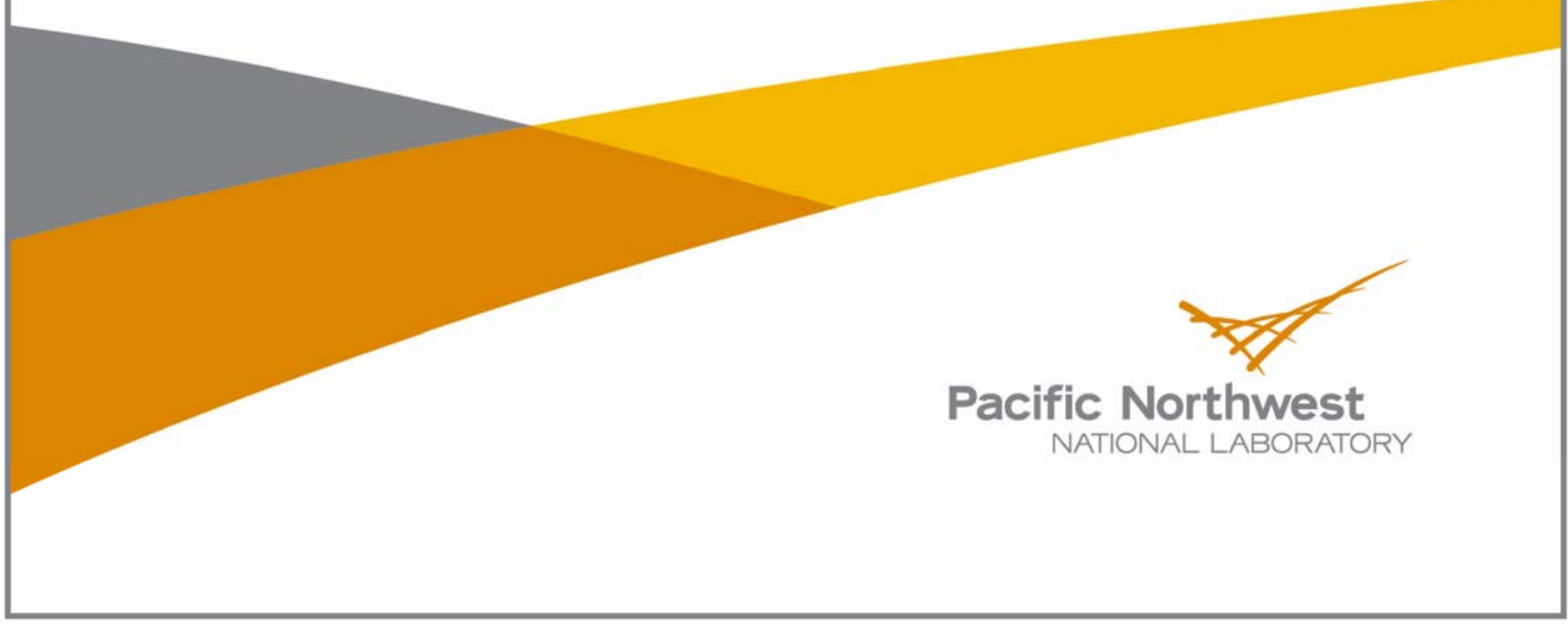




\title{
DISCLAIMER
}

This report was prepared as an account of work sponsored by an agency of the United States Government. Neither the United States Government nor any agency thereof, nor Battelle Memorial Institute, nor any of their employees, makes any warranty, express or implied, or assumes any legal liability or responsibility for the accuracy, completeness, or usefulness of any information, apparatus, product, or process disclosed, or represents that its use would not infringe privately owned rights. Reference herein to any specific commercial product, process, or service by trade name, trademark, manufacturer, or otherwise does not necessarily constitute or imply its endorsement, recommendation, or favoring by the United States Government or any agency thereof, or Battelle Memorial Institute. The views and opinions of authors expressed herein do not necessarily state or reflect those of the United States Government or any agency thereof.

\author{
PACIFIC NORTHWEST NATIONAL LABORATORY \\ operated by \\ BATTELLE \\ for the \\ UNITED STATES DEPARTMENT OF ENERGY \\ under Contract DE-AC05-76RL01830
}

Printed in the United States of America
Available to DOE and DOE contractors from the Office of Scientific and Technical Information,
P.O. Box 62, Oak Ridge, TN 37831-0062;
ph: (865) 576-8401
fax: $(865)$ 576-5728
email: reports@adonis.osti.gov

\begin{abstract}
Available to the public from the National Technical Information Service, U.S. Department of Commerce, 5285 Port Royal Rd., Springfield, VA 22161 ph: (800) 553-6847 fax: $(703) 605-6900$ email: orders@ntis.fedworld.gov online ordering: http://www.ntis.gov/ordering.htm
\end{abstract}

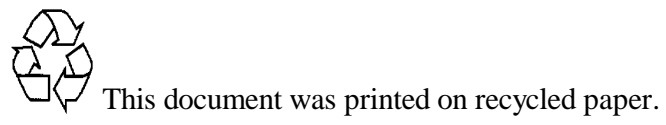


PNNL-17850

\section{Country Report on Building Energy Codes in Australia}

B Shui

M Evans

S Somasundaram

April 2009 



\section{Foreword}

Buildings account for about $30 \%$ of all energy consumption globally and a significant share of greenhouse gas emissions. Building energy codes help ensure that new buildings use energy efficiently, and this can reduce building energy use by $50 \%$ or more compared to buildings designed without energy efficiency in mind. This is important because buildings typically last 30-50 years, and it is much less expensive and time-consuming to design for energy efficiency than to retrofit a building later. Based on the experience of the Asia-Pacific region, it is clear that building energy codes, when implemented, save energy and improve comfort in new buildings. By design, most building energy codes are cost-effective, saving consumers significant amounts of money on their energy bills.

The Asia-Pacific Partnership on Clean Development and Climate (APP) is a publicprivate collaboration to accelerate the development and deployment of clean energy technologies. APP partners include Australia, Canada, China, India, Japan, South Korea and the United States (the U.S.). APP countries account for more than half of global energy consumption, and more than half of global greenhouse gas emissions. APP's Buildings and Appliance Task Force (BATF) provides a forum for APP partners to work together on energy efficiency in buildings and appliances. This report was prepared under the framework of BATF, in particular a BATF project called "Survey building energy codes and develop scenarios for reducing energy consumption through energy code enhancement in APP countries" (BATF-06-24).

At the request of the U.S. Department of Energy, the Pacific Northwest National Laboratory's Joint Global Change Research Institute has prepared a series of reports surveying building energy codes in the seven APP countries. These reports include country reports on building energy codes in each APP partner country and a comparative report based on the country reports. This particular report is the country report on building energy codes in Australia. 


\section{Acknowledgements}

This report owes its existence to the Asia-Pacific Partnership on Clean Development and Climate. We would like to thank all the APP partner countries and experts who collaborated on this project. We are particularly grateful to Dr. Seung-Eon Lee at the Korean Institute of Construction Technology for his oversight of the APP project under which this report was prepared (BATF 06-24). We would also like to thank Mark Ginsberg, Jean Boulin and Marc LaFrance from the U.S. Department of Energy for their leadership and financial support of this work.

Diana Shankle, manager of the PNNL Building Energy Codes Program, has provided moral and intellectual support for this project. Julie Claydon at Australian Government Department of Innovation, Industry, Science and Research, and several reviewers at the Australian Government Department of the Environment, Water, Heritage and the Arts provided very helpful feedback on the report. Mark Halverson at PNNL also reviewed this report, and Alison Delgado and Kate Williams provided editorial assistance. We would also like to express our gratitude to several other individuals who supported or participated in the APP building energy code assessment in various capacities including Joe Huang, Bipin Shah, Elizabeth Malone, Kay Killingstad, Paulette Land and Kim Swieringa. And we would like to acknowledge the Korean Ministry of Knowledge Economy and the Korea Energy Management Corporation which supported the publication of this report. 


\section{Contents}

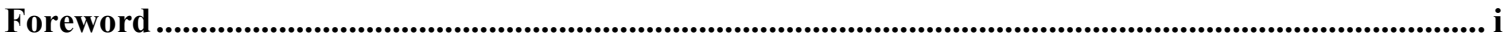

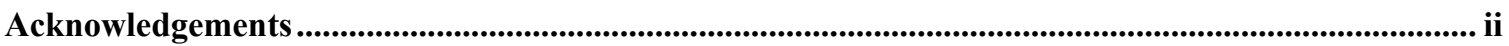

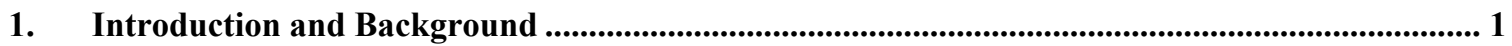

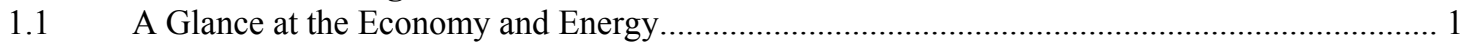

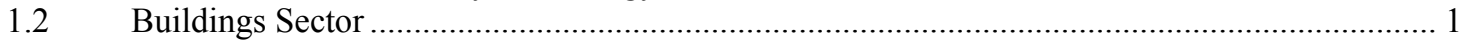

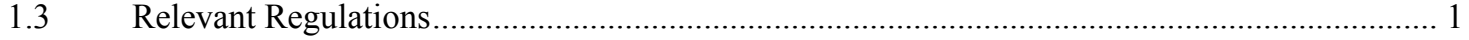

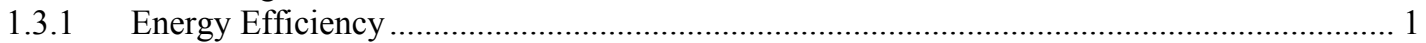

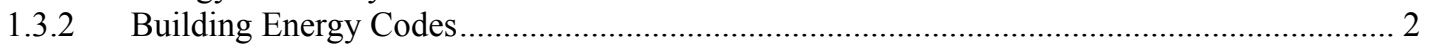

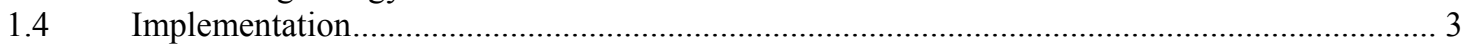

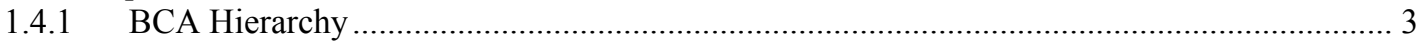

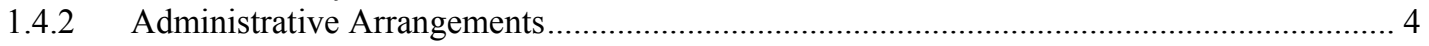

2 Building Energy Requirements in Building Code of Australia 2007.............................................. 5

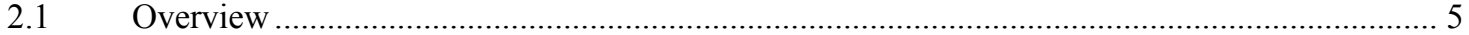

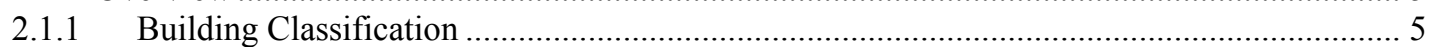

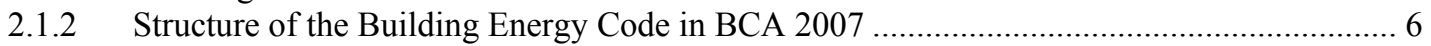

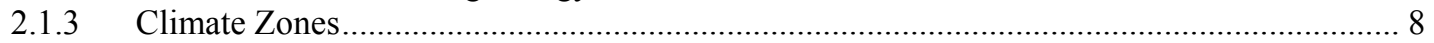

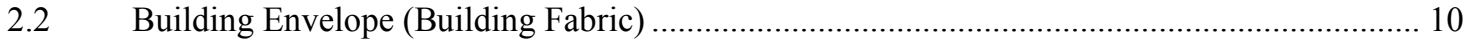

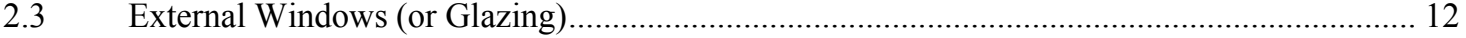

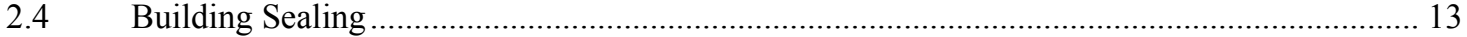

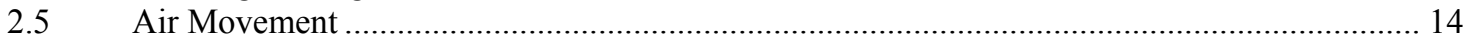

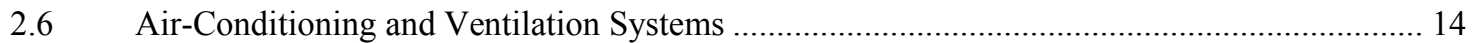

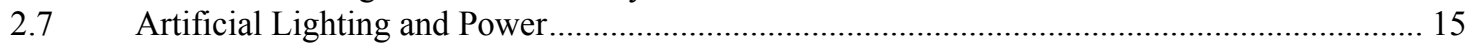

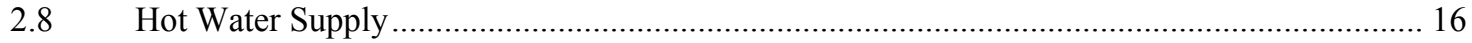

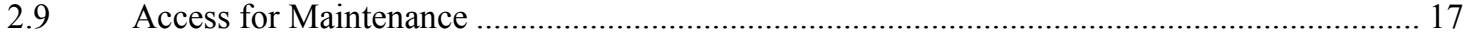

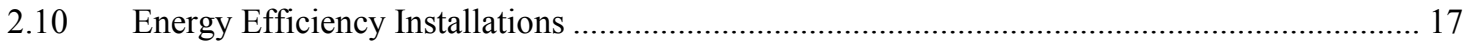

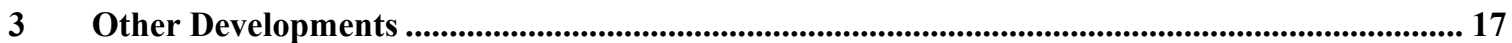

3.1 National Australian Built Environment Rating System (NABERS) …..................................... 17

3.2 Nationwide House Energy Rating Scheme (NatHERS) …................................................. 18

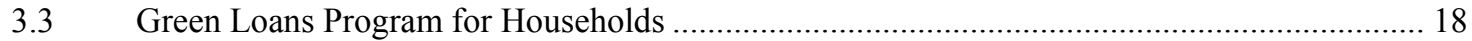

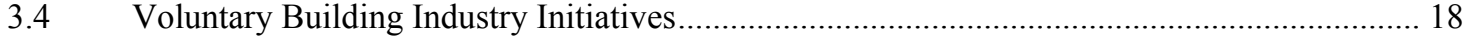

3.5 Energy Efficiency Homes Package ................................................................................... 19

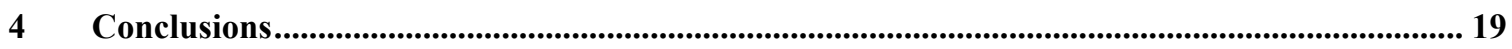

List of Acronyms ................................................................................................................................................... 20

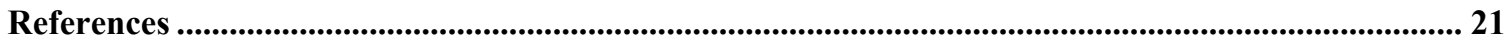

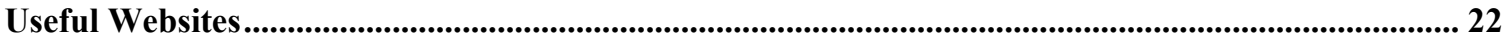




\section{List of Figures}

Figure 1 Energy Consumption by Sector in Australia, 1990-2005 ..................................................... 2

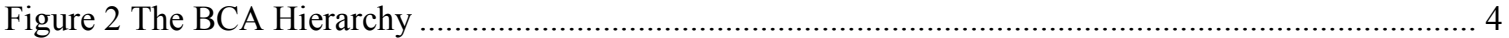

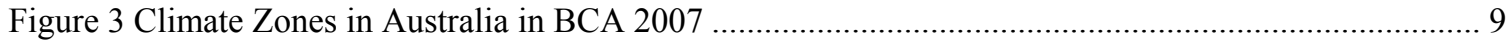

\section{List of Tables}

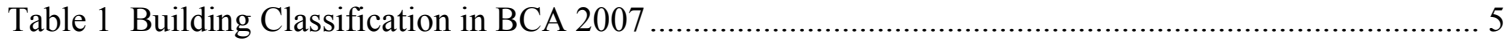

Table 2 Building Code Structure on Energy Efficiency in Volumes One and Two .................................. 7

Table 3 Summary of Specifications in Section J Energy Efficiency of Volume One ............................... 8

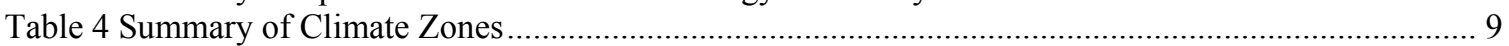

Table 5 Building Envelope in BCA 2007 ........................................................................................ 10

Table 6 The Range of Minimum Total R-values for Roofs (and Ceilings), Walls and Floors by Climate Zone

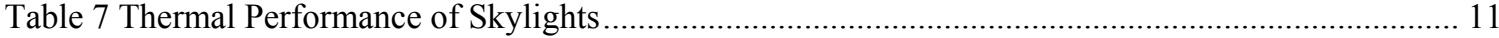

Table 8 External Windows (Glazing) in BCA 2007 ......................................................................... 12

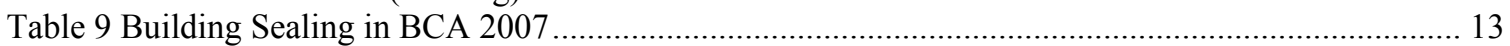

Table 10 Air Movement in Volume One and Volume Two ................................................................... 14 


\section{Introduction and Background}

\subsection{A Glance at the Economy and Energy}

With an impressive annual average growth rate of $3.6 \%$ over the past 15 years, Australia is one of the fastest growing industrialized countries. ${ }^{1}$ In 2007, Australia had a gross domestic product (GDP) of US\$0.8 trillion, making it the smallest economy in the APP. Australia's per capita income is US\$24,142 (IMF, 2008a, b). ${ }^{2}$

Well-endowed with natural resources, Australia is a major exporter of energy-intensive products (Australia is the largest net coal exporter in 2006). As a result, it is an emissionintensive economy. In 2006, Australia emitted 417 Mt of carbon dioxide, which was $1.4 \%$ of the global total that year (EIA, 2008).

\subsection{Buildings Sector}

According to the International Energy Agency (IEA), the buildings sector contributed to almost one-fifth of Australia's annual final energy use ${ }^{3}$ from 1990 to 2005 (Figure 1). This is a smaller role than in many other APP countries, as buildings in Australia consume less energy than the transportation and industrial sectors.

In 2005, the buildings sector consumed 15.9 million tons of oil equivalent (Mtoe). Within the buildings sector, residential buildings account for about two-thirds of the energy use, while commercial buildings account for the rest (or 10.0 vs. 5.8 Mtoe). From 1990 to 2005 , energy demand in the buildings sector grew at a $2.4 \%$ annual growth rate. This growth was faster in commercial rather than residential buildings: $3.4 \%$ annually vs. $1.9 \%$. Growth in energy demand in the buildings sector $(2.4 \%)$ also outpaced the growth in the industrial (1.2\%) and transportation sectors (1.9\%) (IEA, 2007).

\subsection{Relevant Regulations}

\subsubsection{Energy Efficiency}

In the past, Australia's energy policy focused primarily on the supply side (IEA, 2005). However, the government has aggressively pursued energy efficiency in recent years. In 2004, the government published a widely quoted white paper entitled "Securing Australia's Energy Future" which included an examination of the potential of energy efficiency in reducing energy intensity and carbon emissions. The white paper announced several initiatives, including the expansion of the Minimum Energy Performance Standards to cover buildings and more appliances (Australian Government, 2004; IEA, 2005).

\footnotetext{
${ }^{1}$ Specifically, Australia is one of the fastest growing countries in the Organisation for Economic Cooperation and Development (OECD). See The Economist, 2007.

${ }^{2}$ Nominal GDP in current U.S. dollars. Its GDP based on purchasing power parity was US\$0.7 trillion in 2007. Its per capita income on a purchasing power parity basis US $\$ 33,011$.

${ }^{3}$ Final energy use includes consumption of renewable and waste energy.
} 
In August 2004, the Ministerial Council on Energy initiated the National Framework for Energy Efficiency (NFEE), a major national effort to promote energy efficiency, productivity and the environment. In NFEE Stage One, nine integrated and inter-linked policy packages were created, including packages covering: (1) residential buildings, (2) commercial buildings, (3) commercial/industrial energy efficiency, (4) government energy efficiency, (5) appliance and equipment energy efficiency, (6) trade and professional training and accreditation, (7) commercial/industrial sector capacity building, (8) general consumer awareness, and (9) finance sector awareness (NFEE, 2008).

Figure 1 Energy Consumption by Sector in Australia, 1990-2005

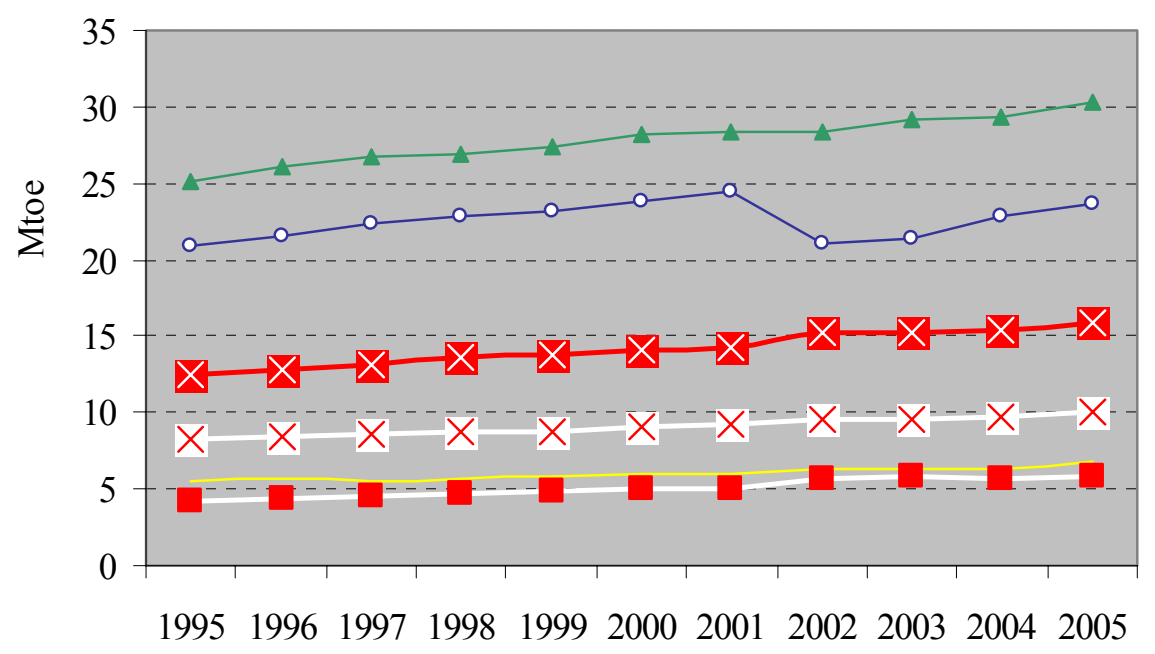

$\begin{array}{ll}- & \text { Transportation } \\ \times- \text { Industry Sector } & \text { Commerce and Public Services } \\ -\mathrm{X}-\text { Building Sector } & \text { Others }\end{array}$

Notes: Energy consumption in this figure refers to final energy use, which includes consumption of renewable and waste energy; the sector "Others" includes agriculture, forestry, fishing, non-specified and non-energy use.

Source: IEA, 2007

On December 13, 2007, the Australian Government, and State and Territory Energy Ministers launched Stage Two of the NFEE. The stage included a package of five new energy efficiency measures, including (1) expanding and enhancing the Minimum Energy Performance Standards (MEPS) program, (2) strategies for high efficiency heating, ventilation and air conditioning (HVAC) systems, (3) phase-out of inefficient incandescent lighting, (4) government leadership though green leases, and (5) development of measures for a national hot water strategy, for later consideration (NFEE, 2008)

\subsubsection{Building Energy Codes}

With participation from all levels of Australian government and from representatives of the building industry, the Australian Building Codes Board (ABCB) is a government body in charge of the development and administration of building codes in Australia. It was officially founded by the Australian Commonwealth, state and territory governments 
in 1994 and reaffirmed in 2006. Key objectives of ABCB include 1) maintaining and updating the Building Code of Australia (BCA), 2) providing regulations to "aid the design, construction and use of buildings throughout Australia," and 3) to support the governmental agenda such as on issues relating to climate change (ABCB, 2008b).

The BCA offers technical provisions for the design and construction of buildings and other structures throughout Australia, allowing for variations by climate zone. It covers structure, fire resistance, services, equipment, energy efficiency, and certain aspects of health and amenities. Energy efficiency measures were introduced into the BCA in January 2003. On energy efficiency, the code allows for either a performance-based approach to compliance (compared to a reference building), or a prescriptive approach based on requirements for specific building components.

In 2000, the Australian Government launched a "two-pronged approach" to combat greenhouse gas emissions from buildings: (1) mandatory minimum energy performance requirements through the $\mathrm{BCA}$, and (2) voluntary initiatives in industry (ABCB, 2008a).

Since 2003, the BCA has been updated annually. This country report was written based on the 2007 version of the BCA (BCA 2007). The most updated version when this report was published is the 2009 version (BCA 2009).

\subsection{Implementation}

\subsubsection{BCA Hierarchy ${ }^{4}$}

The BCA includes both guidance and compliance-level requirements (Figure 2). The guidance levels include objectives (level 1) and functional statements (level 2). The compliance levels consist of performance requirements (level 3) and building solutions (level 4). The performance requirements (level 3) outline a suitable level of performance to be met by building materials, components, design factors and construction methods. Building solutions (level 4) suggest the means of achieving compliance with the performance requirements (ABCB, 2008d).

The BCA provides two compliance methods that can be followed to develop a building solution: a prescriptive ${ }^{5}$ approach with deemed-to-satisfy provisions (level 4a), or alternative solutions (level 4b) (see Figure 2). Designers can choose between the compliance methods, selecting: (1) a prescriptive solution, (2) an alternative solution or (3) a mixture of prescriptive and alternative solutions (Australian Institute of Building, 2004). In order to use an alternative solution, a building designer must use an assessment method (such as documentary evidence, verification, expert judgment or a comparison to the prescriptive approach) to demonstrate that the building will meet the performance requirements in the $\mathrm{BCA}$ ( $\mathrm{ABCB}, 2008 \mathrm{~d})$. In the case of residential houses, verification that the alternative solution achieves the performance requirements can be done by

\footnotetext{
${ }^{4}$ This section is edited based on BCA 2007, http://www.abcb.gov.au/go/about_bca_p2 and http://www.aib.org.au/buildingcodes/bca.htm.

${ }^{5}$ In this country report, we use the term of "prescriptive" to replace the term of "deemed-to-satisfy" appeared in BCA 2007.
} 
achieving a rating of no less than five stars using compliant house energy rating software (see section 3.2).

Figure 2 The BCA Hierarchy

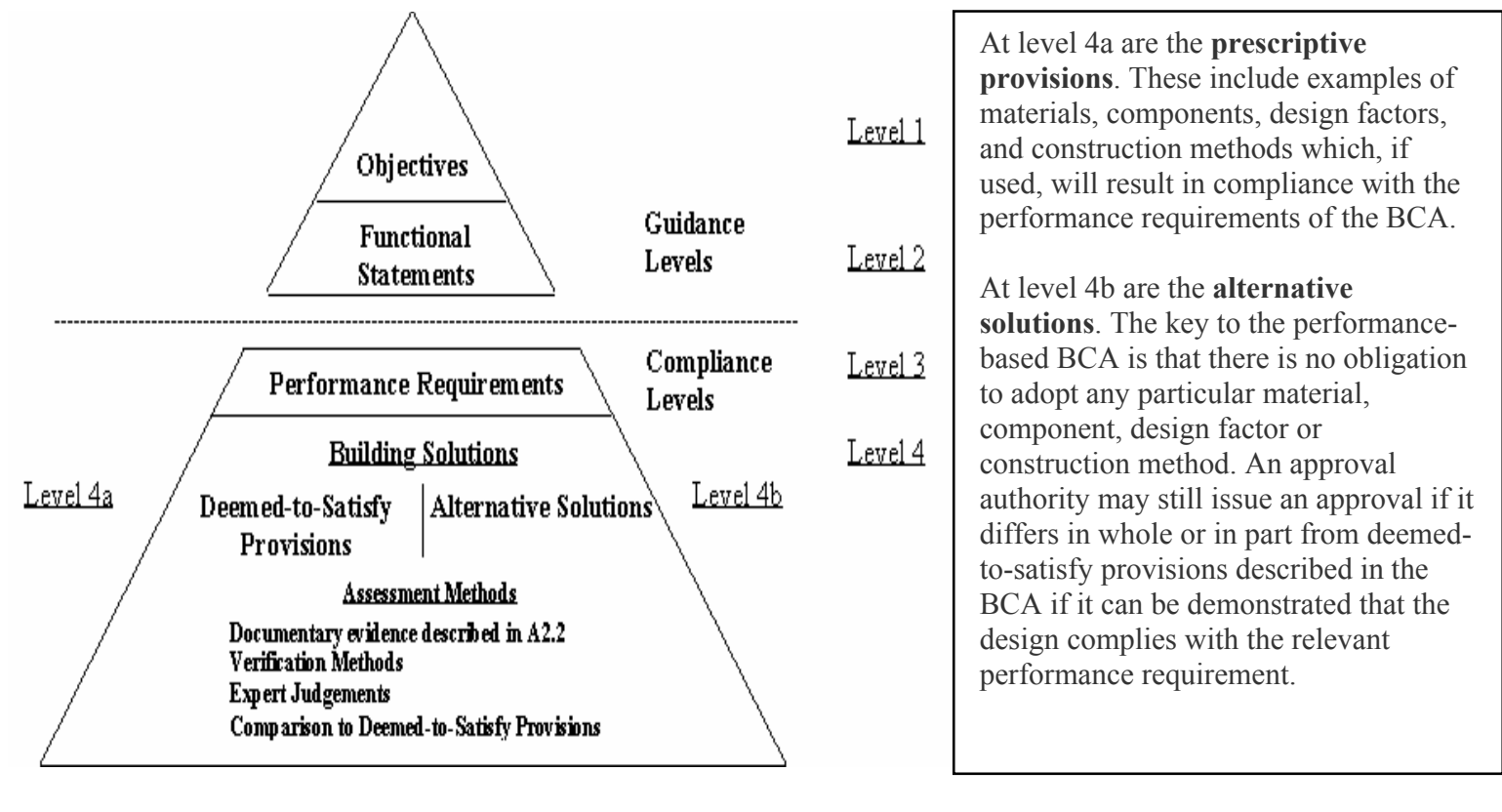

Source: $A B C B, 2008$

\subsubsection{Administrative Arrangements}

The Commonwealth and all of the states and territories had adopted the BCA by early 1998. Enabling building regulatory legislation in each state and territory makes the BCA legally binding, although there is scope for states and territories to vary the BCA's provisions to suit local circumstances. This legislation prescribes the BCA to fulfill any technical requirements which have to be satisfied in order to gain approval of a building proposal (Australian Institute of Building, 2004).

Each state and territory's building regulatory legislation consists of an act of the local parliament and subordinate legislation. Administrative matters typically covered in the enabling or subordinate legislation include procedures for (1) plan submission and approval, (2) issuing of building permits, (3) inspections during and after construction, (4) provision of evidentiary certificates, (5) issuing of certificates of occupancy or compliance, (6) accreditation or approval of materials or components, (7) review and enforcement of standards, and (8) fees and charges (Australian Institute of Building, 2004).

The BCA is not free of charge for users, which is similar to such APP countries as the United States and Canada. There is a national campaign calling for a free BCA to increase compliance (Australia Institute of Building, 2008). 


\section{Building Energy Requirements in Building Code of Australia $2007^{6}$}

\subsection{Overview}

\subsubsection{Building Classification}

The 2007 version of the BCA (BCA 2007) includes two volumes: Volume One covers provisions for multi-unit residential, commercial and public buildings; Volume Two is for detached and attached residential dwellings (Table 1).

Table 1 Building Classification in BCA 2007

\begin{tabular}{|c|c|c|}
\hline Class & Descriptions & $\begin{array}{l}\text { Simplified Name Used } \\
\text { in this Document }\end{array}$ \\
\hline $\mathrm{C} 1$ & $\begin{array}{l}\text { Class 1a: a single detached house, or one of a group of two } \\
\text { or more attached dwellings; Class 1b: boarding houses, } \\
\text { guest houses or hostels with a total area not exceeding } 300 \\
\text { square meters }\end{array}$ & A residential house \\
\hline $\mathrm{C} 2$ & $\begin{array}{l}\text { A multi-family residential building or a building containing } \\
2 \text { or more sole-occupancy units, each being a separate } \\
\text { dwelling }\end{array}$ & $\begin{array}{l}\text { A multi-family } \\
\text { residential building }\end{array}$ \\
\hline $\mathrm{C} 3$ & $\begin{array}{l}\text { A residential building other than a Class } 1 \text { or Class } 2 \\
\text { building, including residential parts of a hotel or motel, a } \\
\text { school, a health-care building, or a detention center }\end{array}$ & A hotel or dormitory \\
\hline $\mathrm{C} 4$ & $\begin{array}{l}\text { A dwelling in a building that is Class } 5,6,7,8 \text { or } 9 \text { if it is } \\
\text { the only dwelling in the building }\end{array}$ & $\begin{array}{l}\text { A dwelling in a } \\
\text { commercial building }\end{array}$ \\
\hline $\mathrm{C} 5$ & An office building & An office building \\
\hline C6 & A retail building & A retail building \\
\hline $\mathrm{C} 7$ & $\begin{array}{l}\text { Class 7a: parking lot or garage; Class } 7 \mathrm{~b} \text { : a place used for } \\
\text { storage, or display of goods or produce for sale by wholesale }\end{array}$ & $\begin{array}{l}\text { A commercial garage } \\
\text { or storage unit }\end{array}$ \\
\hline $\mathrm{C} 8$ & $\begin{array}{l}\text { A laboratory or a building in which a handicraft or process } \\
\text { for production occurs }\end{array}$ & A laboratory building \\
\hline C9 & $\begin{array}{l}\text { Class 9a: health-care building; Class 9b: an assembly } \\
\text { building including a trade workshop or a laboratory in a } \\
\text { school; Class 9c: senior citizen housing }\end{array}$ & $\begin{array}{l}\text { Miscellaneous } \\
\text { commercial buildings }\end{array}$ \\
\hline $\mathrm{C} 10$ & $\begin{array}{l}\text { A non-habitable building or structure, including } \\
\text { Class 10a: such as a private garage, carport or shed; Class } \\
\text { 10b: such as a fence, mast, retaining or free-standing wall or } \\
\text { swimming pool }\end{array}$ & A private garage \\
\hline
\end{tabular}

In this country report, the buildings in the $\mathrm{C} 2, \mathrm{C} 3, \mathrm{C} 4$ or $\mathrm{C} 9 \mathrm{c}$ categories are called dwelling-oriented buildings. The remaining buildings in Volume One, including buildings in the $\mathrm{C} 5, \mathrm{C} 6, \mathrm{C} 7, \mathrm{C} 8, \mathrm{C} 9 \mathrm{a}$ and $\mathrm{C} 9 \mathrm{~b}$ categories, are called non-dwelling buildings. These simplified terms are not part of the official BCA 2007 terminology.

\footnotetext{
${ }^{6}$ This country report was written based on BCA 2007. BCA 2009 is the latest version available for purchase.
} 
In order to facilitate the reading and understanding of specific provisions for a dozen building types, each building classification is simplified with a representative building type and presented in the column "simplified name used in this document." Please note that this simplification is not part of the official BCA 2007 terminology.

\subsubsection{Structure of the Building Energy Code in BCA 2007}

BCA 2007 has ten sections in Volume One, including (Section A) general provisions, (B) structure, (C) fire resistance, (D) access, (E) services and equipment, (F) health and amenity, (G) ancillary provisions, (H) special use buildings, (I) maintenance, and (J) energy efficiency. There are three sections in Volume Two, including (Section 1) general requirements, (2) performance provisions and (3) acceptable construction.

The BCA includes one Part (Part I2) on energy efficiency installation under Section I and eight Parts (Part J1 to Part J8) on energy efficiency for buildings under Section J in Volume One (Table 2). The contents of energy efficiency for residential houses are mainly located in two places in Volume Two: Section 2, performance requirements (general descriptions on energy efficiency) and Part 3.12 of Section 3 (the specific provisions for energy efficiency of building components). Section $\mathrm{J}$ also contains seven specifications for buildings (Table 3 ).

As noted above, all buildings and houses must meet the mandatory energy efficiency clauses of the BCA, as well as either the prescriptive provisions ${ }^{7}$ or the alternative, performance-based provisions.

\footnotetext{
${ }^{7}$ See J1.0, J2.0, J3.0, J4.0, J5.0, J6.0, J7.0 and J8.0.
} 
Table 2 Building Code Structure on Energy Efficiency in Volumes One and Two

\begin{tabular}{|c|c|c|c|}
\hline \multicolumn{2}{|c|}{$\begin{array}{c}\text { Section or Part Number in the } \\
\text { BCA } 2007\end{array}$} & \multirow{2}{*}{$\begin{array}{c}\text { Section or Part } \\
\text { Title in BCA } 2007\end{array}$} & \multirow[b]{2}{*}{ Description } \\
\hline $\begin{array}{c}\text { Buildings } \\
\text { (Volume One) }\end{array}$ & $\begin{array}{c}\text { Residential } \\
\text { Houses } \\
\text { (Volume Two) } \\
\end{array}$ & & \\
\hline Section J & $\begin{array}{l}\text { Section } 2 \\
\text { and Part } 3.12\end{array}$ & Energy Efficiency & \\
\hline JO1 & $\mathrm{O} 2.6$ & Objective & The goal of the regulation \\
\hline JF1 & F2.6 & Functional Statements & $\begin{array}{l}\text { General terms on how a building could } \\
\text { be expected to satisfy the objectives }\end{array}$ \\
\hline $\begin{array}{l}\text { JP1 (Buildings) } \\
\text { JP2 (Services) }\end{array}$ & $\begin{array}{l}\text { P2.6.1 } \\
\text { (Buildings) } \\
\text { P2.6.2 } \\
\text { (Services) }\end{array}$ & $\begin{array}{l}\text { Performance } \\
\text { Requirement }\end{array}$ & $\begin{array}{l}\text { Energy efficiency appropriate to the } \\
\text { function and use of the building and its } \\
\text { services }\end{array}$ \\
\hline JV1-JV3 & $\begin{array}{l}\text { V2.6.2.1 - } \\
\text { V2.6.2.2 }\end{array}$ & Verification Methods & $\begin{array}{l}\text { Explanations of the methods for } \\
\text { verifying compliance }\end{array}$ \\
\hline JV & $\begin{array}{l}\text { Not Applied } \\
\text { (N.A.) }\end{array}$ & $\begin{array}{l}\text { Annual Energy } \\
\text { Consumption } \\
\text { Calculation } \\
\end{array}$ & $\begin{array}{l}\text { Parameters used in annual energy } \\
\text { consumption calculation }\end{array}$ \\
\hline Part J1 & Part 3.12.1 & Building Envelope $^{8}$ & $\begin{array}{l}\text { Provisions for thermal insulation, roofs } \\
\text { and ceilings, walls and other parts of the } \\
\text { building envelope }\end{array}$ \\
\hline Part J2 & Part 3.12.2 & External Glazing & Provisions for windows and shading \\
\hline Part J3 & Part 3.12.3 & Building Sealing & $\begin{array}{l}\text { Provisions for chimneys and flues, } \\
\text { skylights, doors and windows, exhaust } \\
\text { fans and evaporative coolers }\end{array}$ \\
\hline Part J4 & Part 3.12.4 & Air Movement & $\begin{array}{l}\text { Provisions for air movement, ventilation } \\
\text { openings, ceiling fans and evaporative } \\
\text { coolers }\end{array}$ \\
\hline Part J5 & $\begin{array}{l}\text { Not Applied } \\
\text { (N.A.) }\end{array}$ & $\begin{array}{l}\text { Air-Conditioning and } \\
\text { Ventilation Systems }\end{array}$ & $\begin{array}{l}\text { Requirements for air-conditioning and } \\
\text { ventilation systems, time switches, } \\
\text { heating and chilling systems, and } \\
\text { miscellaneous exhaust systems }\end{array}$ \\
\hline Part J6 & N.A. & $\begin{array}{l}\text { Artificial Lighting and } \\
\text { Power }\end{array}$ & $\begin{array}{l}\text { Provisions for interior and exterior } \\
\text { lighting }\end{array}$ \\
\hline Part J7 & $\begin{array}{l}\text { Part 3.12.5.0 - } \\
3.12 .5 .2\end{array}$ & Hot Water Supply & $\begin{array}{l}\text { Provisions for thermal insulation, central } \\
\text { heating water piping, and heating and } \\
\text { cooling ductwork }\end{array}$ \\
\hline Part J8 & N.A. & $\begin{array}{l}\text { Access for } \\
\text { Maintenance }\end{array}$ & Provisions for maintenance access \\
\hline Section I & N.A. & Maintenance & \\
\hline Part I2 & N.A. & $\begin{array}{l}\text { Energy Efficiency } \\
\text { Installations }\end{array}$ & $\begin{array}{l}\text { Provisions for energy efficiency } \\
\text { installations }\end{array}$ \\
\hline $\begin{array}{l}\text { Specification J1.2 } \\
\text { to J6 }\end{array}$ & N.A. & Specifications & $\begin{array}{l}\text { Specific provisions for thermal } \\
\text { conductivity, insulation, lighting and } \\
\text { power control }\end{array}$ \\
\hline
\end{tabular}

Source: BCA 2007

\footnotetext{
${ }^{8}$ For consistency with the other country reports, we use the term "building envelope" in this report instead of "building fabric," which appears in BCA 2007.
} 
Table 3 Summary of Specifications in Section $J$ Energy Efficiency of Volume One

\begin{tabular}{|c|c|c|}
\hline Theme & $\begin{array}{l}\text { Specification Number } \\
\text { and Title in } \\
\text { Volume One } \\
\end{array}$ & Description \\
\hline \multirow{4}{*}{$\begin{array}{l}\text { Thermal } \\
\text { conductivity }\end{array}$} & Material Properties (J1.2) & $\begin{array}{l}\text { Thermal conductivity }(\mathrm{W} / \mathrm{m} \cdot \mathrm{K}) \text { of typical wall, roof, } \\
\text { ceiling and floor materials; typical R-values for } \\
\text { airspaces and air films; typical thermal properties } \\
\text { (R-value added by a reflective surface) for reflective } \\
\text { surfaces and airspaces in roofs }\end{array}$ \\
\hline & $\begin{array}{l}\text { Roof and Ceiling } \\
\text { Construction (J1.3) }\end{array}$ & $\begin{array}{l}\text { Typical R-values (ventilated vs. unventilated) for } \\
\text { roof and ceiling construction by roof construction } \\
\text { type }\end{array}$ \\
\hline & Wall Construction (J1.5) & $\begin{array}{l}\text { Typical R-values for wall construction by external } \\
\text { wall construction type }\end{array}$ \\
\hline & Floor Construction (J1.6) & $\begin{array}{l}\text { Typical R-values for floor construction (for a floor } \\
\text { without a floor heating system) by floor } \\
\text { construction type }\end{array}$ \\
\hline \multirow[t]{2}{*}{ Insulation } & $\begin{array}{l}\text { Ductwork Insulation and } \\
\text { Sealing (J5.2) }\end{array}$ & $\begin{array}{l}\text { Requirements for sealing and insulating supply and } \\
\text { return ductwork used in a system that heats or cools } \\
\text { a building. Minimal total R-values for ductwork and } \\
\text { fittings }\end{array}$ \\
\hline & $\begin{array}{l}\text { Insulation of Piping, } \\
\text { Vessels, Heat Exchangers } \\
\text { and Tanks (J5.4) }\end{array}$ & $\begin{array}{l}\text { Requirements for insulating piping, vessels, heat } \\
\text { exchangers, and tanks containing heated or chilled } \\
\text { fluid, such as minimum total R-value for piping }\end{array}$ \\
\hline $\begin{array}{l}\text { Lighting and } \\
\text { Power } \\
\text { Control }\end{array}$ & $\begin{array}{l}\text { Lighting and Power } \\
\text { Control Devices (J6) }\end{array}$ & $\begin{array}{l}\text { Requirements for lighting and power control devices } \\
\text { including timers, time switches, motion detectors } \\
\text { and daylight control devices }\end{array}$ \\
\hline
\end{tabular}

Source: $B C A 2007$

\subsubsection{Climate Zones}

Australia's climate is arid to semiarid in the west, temperate in the south and east, and tropical in the north (ABCB, 2008c; McGlynn, 2006). The BCA divides Australia into eight climate zones. Climate zone 1 , located in the far north, has very humid summers with warm winters, and climate zone 8 , located in the far south, is the coldest region (Figure 3 and Table 4).

Notice that the most significant difference between BCA 2007 and BCA 2009 is the climate zone map; in BCA 2009, a few local geographic areas changed climate zone. 
Figure 3 Climate Zones in Australia in BCA 2007

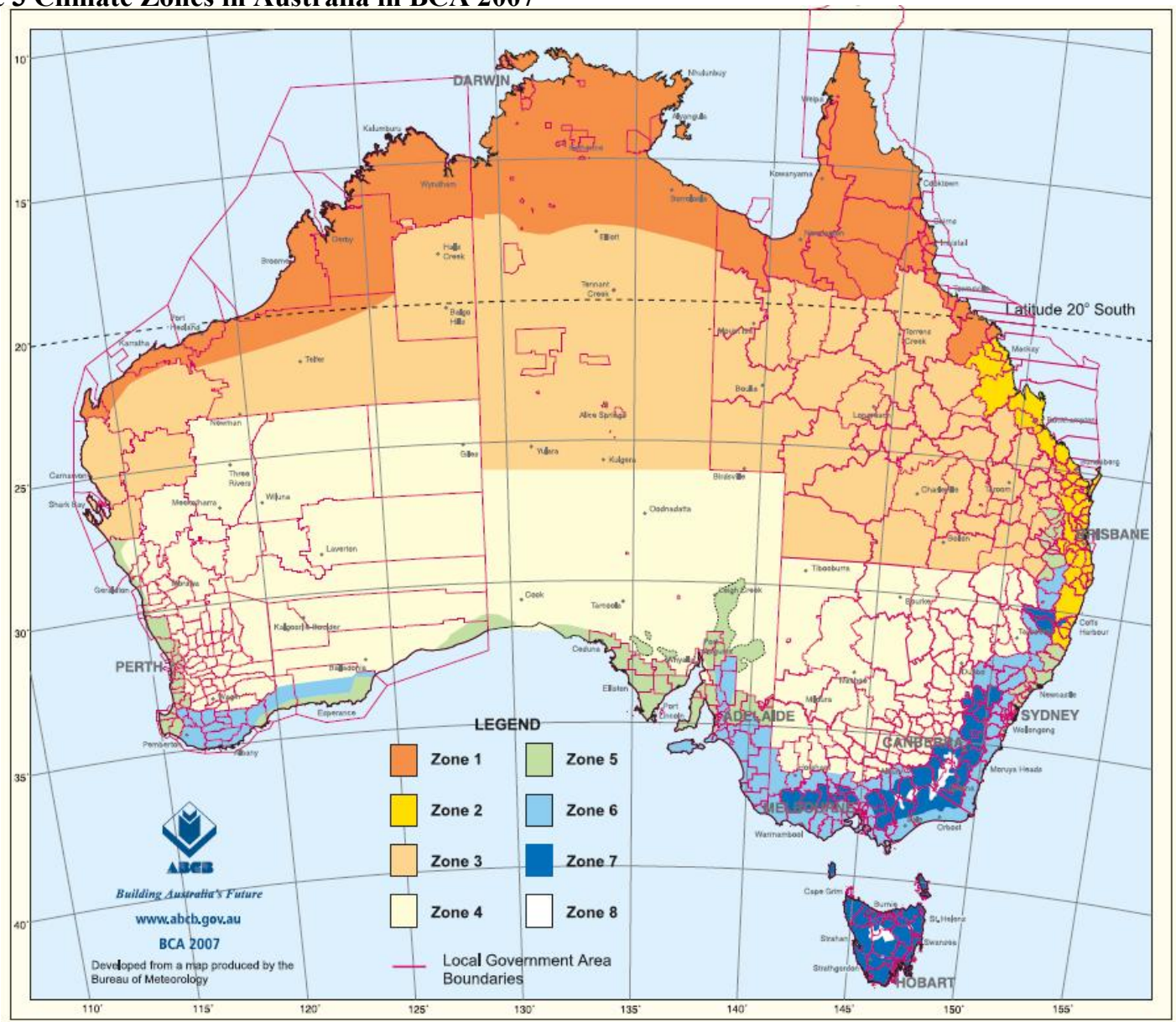

Source: $A B C B, 2008 c$

Table 4 Summary of Climate Zones

\begin{tabular}{|c|c|c|c|c|c|}
\hline $\begin{array}{c}\text { Climate } \\
\text { zone }\end{array}$ & Description & $\begin{array}{c}\text { Average 3 pm } \\
\text { January water } \\
\text { vapour pressure }\end{array}$ & $\begin{array}{c}\text { Average January } \\
\text { maximum } \\
\text { temperature }\end{array}$ & $\begin{array}{c}\text { Average July } \\
\text { mean } \\
\text { temperature }\end{array}$ & $\begin{array}{c}\text { Average annual } \\
\text { heating degree } \\
\text { days }\end{array}$ \\
\hline 1 & $\begin{array}{c}\text { High humidity summer, } \\
\text { warm winter }\end{array}$ & $\geq 2.1 \mathrm{kPa}$ & $\geq 30^{\circ} \mathrm{C}$ & - & - \\
\hline 2 & $\begin{array}{c}\text { Warm humid summer, } \\
\text { mild winter }\end{array}$ & $\geq 2.1 \mathrm{kPa}$ & $<30^{\circ} \mathrm{C}$ & - & - \\
\hline 3 & $\begin{array}{c}\text { Hot dry summer, warm } \\
\text { winter }\end{array}$ & $\leq 2.1 \mathrm{kPa}$ & $\geq 30^{\circ} \mathrm{C}$ & $<14^{\circ} \mathrm{C}$ & - \\
\hline 4 & $\begin{array}{c}\text { Hot dry summer, cool } \\
\text { winter }\end{array}$ & $\leq 2.1 \mathrm{kPa}$ & $\geq 30^{\circ} \mathrm{C}$ & $<14^{\circ} \mathrm{C}$ & - \\
\hline 5 & Warm temperate & $\leq 2.1 \mathrm{kPa}$ & $<30^{\circ} \mathrm{C}$ & - & $<1000$ \\
\hline 6 & Mild temperate & $\leq 2.1 \mathrm{kPa}$ & $<30^{\circ} \mathrm{C}$ & & 2000 to alpine \\
\hline 7 & Cool temperate & $\leq 2.1 \mathrm{kPa}$ & $<30^{\circ} \mathrm{C}$ & & - \\
\hline 8 & \multicolumn{2}{|c|}{ Areas defined as "alpine" in the BCA } & \\
\hline
\end{tabular}

Source: McGlynn, 2006 


\subsection{Building Envelope (Building Fabric) ${ }^{9}$}

All of the provisions for the building envelope apply to most building types ${ }^{10}$, including buildings and residential houses (Table 5). ${ }^{11}$

Table 5 Building Envelope in BCA 2007

\begin{tabular}{|l|l|l|}
\hline \multicolumn{1}{|c|}{$\begin{array}{c}\text { Buildings } \\
\text { (Volume One) }\end{array}$} & \multicolumn{1}{|c|}{$\begin{array}{c}\text { Residential Houses } \\
\text { (Volume Two) }\end{array}$} & \multicolumn{1}{c|}{ Description } \\
\hline Prescriptive Provisions & N.A. & N.A. \\
\hline Application & Application & Building classes applied \\
\hline $\begin{array}{l}\text { General thermal } \\
\text { construction }\end{array}$ & $\begin{array}{l}\text { Building envelope } \\
\text { thermal insulation }\end{array}$ & Requirements for insulation \\
\hline $\begin{array}{l}\text { Roof and ceiling } \\
\text { construction }\end{array}$ & Roof & $\begin{array}{l}\text { The minimum total R-values in } \\
\text { roofs and ceilings by climate zone }\end{array}$ \\
\hline Skylights ${ }^{12}$ & Skylights & $\begin{array}{l}\text { Requirements for skylight area and } \\
\text { corresponding total U-values and } \\
\text { solar heat gain coefficient }\end{array}$ \\
\hline Walls & External walls & $\begin{array}{l}\text { The minimum total R-values of } \\
\text { external walls by climate zone }\end{array}$ \\
\hline Floors & Floors & $\begin{array}{l}\text { The minimum total R-value by } \\
\text { floor types and climate zone }\end{array}$ \\
\hline & $\begin{array}{l}\text { Attached primary garage } \\
\text { buildings }\end{array}$ & $\begin{array}{l}\text { Building description and the } \\
\text { required thermal performance }\end{array}$ \\
\hline
\end{tabular}

Thermal Insulation: The building envelope must have insulation that complies with the Australian-New Zealand standards (AS/NZS 4859) ${ }^{13}$. There are detailed requirements on how insulation is to be installed. Insulation must form a continuous barrier with ceilings, walls, bulkheads, floors and the like. ${ }^{14}$ The BCA 2007 provides the minimum total Rvalue for roofs or ceilings, walls and floors of buildings and houses (Table 6).

\footnotetext{
${ }^{9}$ See Part J1 in Volume One for commercial buildings, and Part 3.12.1 in Volume Two for residential houses.

${ }^{10}$ The most buildings exclude garage, storage, or laboratory buildings that do not have a conditioned space, or an atrium or solarium that is not a conditioned space and is separated from the remainder of the building by an envelope.

${ }^{11}$ See Part J1.1 of BCA 2007.

${ }^{12}$ Known as roof lights in Australia.

${ }_{13}$ AS/NZS 4859 provides general criteria, technical provisions and test procedures for building insulation.

${ }^{14}$ See Parts J1.2, and 3.12.1.1 of BCA 2007.
} 
Table 6 The Range of Minimum Total R-values for Roofs (and Ceilings), Walls and Floors by Climate Zone

\begin{tabular}{|c|c|c|c|}
\hline & $\begin{array}{c}\text { Dwelling-oriented } \\
\text { Buildings }\end{array}$ & $\begin{array}{c}\text { Non-dwelling } \\
\text { Buildings }\end{array}$ & Residential Houses \\
\hline $\begin{array}{l}\text { Roofs and ceilings in } \\
\text { general }\end{array}$ & $\begin{array}{c}2.2(\mathrm{Z1}) \\
-4.3(\mathrm{Z} 8) \\
\end{array}$ & $\begin{array}{c}3.2(\mathrm{Z} 1 \text { to } \mathrm{Z6}) \\
-4.3(\mathrm{Z} 8)\end{array}$ & $\begin{aligned} 2.7(Z 1) \\
-4.8(Z 8) \\
\end{aligned}$ \\
\hline $\begin{array}{l}\text { Roofs and ceilings } \\
\text { below a non- } \\
\text { conditioned space }\end{array}$ & $\begin{aligned} & 1.1(\mathrm{Z1}) \\
- & 2.15(\mathrm{Z} 8)\end{aligned}$ & $\begin{array}{l}1.6(\mathrm{Z} 1 \text { to } \mathrm{Z6}) \\
-2.15(\mathrm{Z} 8)\end{array}$ & \\
\hline Walls & $\begin{array}{l}1.4(\mathrm{Z} 1,2 \text { and } 3) \\
-2.8(\mathrm{Z} 8),\end{array}$ & $\begin{array}{c}1.8(\mathrm{Z} 1 \text { to } 7) \\
-2.8(\mathrm{Z} 8)\end{array}$ & $\begin{array}{c}1.9(\mathrm{Z} 1,2 \text { and } 3)-3.3 \\
\text { (zone 8) }\end{array}$ \\
\hline Floors & $\begin{array}{l}1.0(\mathrm{Z} 6 \text { and } 7) \\
-2.5(\mathrm{Z} 8)\end{array}$ & $\begin{array}{c}1.5(\mathrm{Z} 1,3,4,6, \text { and } \\
7)-2.5(\mathrm{Z} 8)\end{array}$ & $\begin{aligned} & 2.0(\mathrm{Z} 4) \\
- & 3.0(\mathrm{Z} 8)\end{aligned}$ \\
\hline
\end{tabular}

Notes:

1. Z1 refers to climate zone 1, which has a high humidity summer with a warm winter and is located in the far north of Australia. Z8 refers to climate zone 8, which is an "alpine" area and is located in the far south (Figure 3 Climate Zones in Australia).

2. Dwelling oriented buildings include multi-family buildings (C2), hotels or dormitories (C3), dwelling(s) in commercial buildings (C4) or senior housing in miscellaneous commercial buildings (C9c). 3. Non-dwelling buildings include office buildings (C5), retail buildings (C6), public garages (C7), laboratory buildings (C8), health care buildings (C9a) and laboratory buildings in schools (C9b).

Skylights in buildings and residential houses should be between $1.5 \%$ and $10 \%$ of the floor area of the room or space. A list of prescriptive, total U-value and Solar Heat Gain Coefficient requirements should be met. ${ }^{15}$ Skylight areas can exceed $10 \%$ when the skylights are the only lighting source. BCA 2007 also provides thermal performance of skylights (Table 7).

Table 7 Thermal Performance of Skylights

\begin{tabular}{|l|c|c|c|}
\hline \multirow{2}{*}{$\begin{array}{l}\text { Skylight Shaft } \\
\text { Index }\end{array}$} & \multicolumn{3}{|c|}{ Ratio of Total Area of Skylights to Floor Area Served } \\
\cline { 2 - 4 } & $\mathbf{1 . 5 \%}<$ Ratio $<=\mathbf{3 \%} \%$ & $\mathbf{3 \%}<$ Ratio $<=\mathbf{5 \%}$ & $\mathbf{5 \%}$ Ratio $<=\mathbf{1 0 \%}$ \\
\hline$<0.5$ & $\begin{array}{c}\text { SHGC }<0.75 \\
\text { Total U-value }<5.0\end{array}$ & $\begin{array}{c}\text { SHGC }<0.55 \\
\text { Total U-value }<5.0\end{array}$ & $\begin{array}{c}\text { SHGC }<0.25 \\
\text { Total U-value }<2.0\end{array}$ \\
\hline 0.5 to $<1.0$ & Total U-value $<5.0$ & $\begin{array}{c}\text { SHGC }<0.70 \\
\text { Total U-value }<5.0\end{array}$ & $\begin{array}{c}\text { SHGC }<0.35 \\
\text { Total U-value }<2.5\end{array}$ \\
\hline 1.0 to $<2.5$ & Total U-value $<5.0$ & Total U-value $<5.0$ & $\begin{array}{c}\text { SHGC }<0.45 \\
\text { Total U-value }<2.5\end{array}$ \\
\hline 2.5 and above & Total U-value $<5.0$ & Total U-value $<5.0$ & $\begin{array}{c}\text { SHGC }<0.55 \\
\text { Total U-value }<5.0\end{array}$ \\
\hline
\end{tabular}

Note: The skylight shaft index is determined by measuring the distance from the center of the shaft at the roof to the center of the shaft at the ceiling level and dividing it by the average internal dimension of the shaft opening at the ceiling level.

\footnotetext{
${ }^{15}$ See Parts J1.4 and 3.12.1.3 of BCA 2007.
} 


\subsection{External Windows (or Glazing) ${ }^{16}$}

The BCA contains specific provisions on the energy efficiency characteristics of windows (Table 8 ). The provisions on external windows apply to most building types except for commercial garages and other unconditioned spaces. ${ }^{17}$ The windows must be designed and installed according to either method one (for dwelling buildings) or method two (for non-dwelling buildings). Notice that window provisions in Residential Houses (Volume Two) are expressed in a similar way to Method 1 with slight differences (such as on slab-on-ground concession etc).

Table 8 External Windows (Glazing) in BCA 2007

\begin{tabular}{|l|l|l|}
\hline \multicolumn{1}{|c|}{$\begin{array}{c}\text { Buildings } \\
\text { (Volume One) }\end{array}$} & \multicolumn{1}{|c|}{$\begin{array}{c}\text { Residential Houses } \\
\text { (Volume Two) }\end{array}$} & \multicolumn{1}{c|}{ Description } \\
\hline Prescriptive Provisions & N.A. & N.A. \\
\hline Application & Application & Applicable building classes \\
\hline Glazing - Method 1 & External glazing & Description of Method 1 \\
\hline Glazing - Method 2 & & Description of Method 2 \\
\hline Shading & Shading & $\begin{array}{l}\text { The minimum total R-values of } \\
\text { external walls by climate zone }\end{array}$ \\
\hline
\end{tabular}

Method One vs. Method Two

In method one, the estimated aggregate conductance is the sum of products between the area of each glazing element and the total U-value of the same glazing element. This aggregate conductance value must not exceed the allowances obtained by multiplying their floor area, measured within the enclosing walls, by the conductance $\left(\mathrm{C}_{\mathrm{U}}\right)$. The estimated aggregate solar heat gain is the sum of the products between the area of each glazing element, the solar heat gain of the same glazing element and the solar exposure factor for the same glazing element. This aggregate solar heat gain must not exceed the allowances obtained by multiplying their floor area, measured within the enclosing walls, by solar heat gain $\left(\mathrm{C}_{\mathrm{SHGC}}\right)$. Both $\mathrm{C}_{\mathrm{U}}$ and $\mathrm{C}_{\mathrm{SHGC}}$ are constants varied by climate zone and referred to in Table J2.3a (Part J2.3 and Part 3.12.2.1)

In method two, the estimated aggregate air conditioning energy value is calculated by adding the air-conditioning energy value through each glazing element. This estimated aggregate airconditioning energy value attributble to the glazing must not exceed the allowance obtained by multiplying the facade area of the orientation by the energy index in Table J2.4a (Part J2.4).

Source: BCA 2007

The BCA requires shading in some cases to comply with the window compliance methods described above. In these cases, shading must be from permanent, external projections, such as verandas or balconies, or external shading devices, such as shutters or blinds. ${ }^{18}$

\footnotetext{
${ }^{16}$ See Part J2 in Volume One of BCA 2007 for commercial buildings, and Part 3.12.21 in Volume Two of BCA 2007 for residential houses.

${ }^{17}$ See Part J2.1 and Part 3.12.2 of BCA 2007.

${ }^{18}$ See Part J2.5 and Part 3.12.2 of BCA 2007.
} 


\subsection{Building Sealing ${ }^{19}$}

The provisions on building sealing apply to most building types (Table 9). ${ }^{20}$

Table 9 Building Sealing in BCA 2007

\begin{tabular}{|c|c|c|}
\hline $\begin{array}{c}\text { Buildings } \\
\text { (Volume One) }\end{array}$ & $\begin{array}{l}\text { Residential Houses } \\
\text { (Volume Two) }\end{array}$ & Description \\
\hline Prescriptive provisions & N.A. & N.A. \\
\hline Application of part & Application & Applicable building classes \\
\hline Chimneys and flues & Chimneys and flues & \multirow{6}{*}{$\begin{array}{l}\text { Specific requirements for sealing } \\
\text { each of these building } \\
\text { components }\end{array}$} \\
\hline Skylights & Skylights & \\
\hline Windows and doors & $\begin{array}{l}\text { External windows and } \\
\text { doors }\end{array}$ & \\
\hline Exhaust fans & External walls & \\
\hline $\begin{array}{l}\text { Construction of roofs, walls } \\
\text { and floors }\end{array}$ & $\begin{array}{l}\text { Construction of roofs, } \\
\text { walls and floors }\end{array}$ & \\
\hline Evaporative coolers & Evaporative coolers & \\
\hline
\end{tabular}

The chimney or flue of an open solid-fuel burning appliance must have a damper or flap that can be closed to seal the chimney or flue. ${ }^{21}$

Skylights must be sealed when serving a conditioned space or a habitable room in areas with cool to cold winters (zones 4, 6, 7 and 8). Skylights that have moveable windows must also include a weatherproof seal of the moveable components. ${ }^{22}$

Doors and windows in the building envelope in areas with cool to cold winters must have weatherstripping to limit air infiltration. These provisions do not apply to (a) external louver doors and windows, and (b) windows complying with the maximum air infiltration rates provided in AS $2047 .^{23}$

Miscellaneous exhaust fans, such as bathroom or kitchen exhaust fans, must have a selfclosing damper or the like when serving conditioned or habitable spaces in areas with cool to cold winters. ${ }^{24}$

In order to restrict air leakage from buildings, the BCA sets construction requirements for roofs, walls, floors, windows and other openings. These requirements do not apply to openings for smoke ventilation. ${ }^{25}$

\footnotetext{
${ }^{19}$ See Part J3 in Volume One of BCA 2007 for commercial buildings, and Part 3.12.3 in Volume Two of BCA 2007 for residential houses.

${ }^{20}$ See Parts J3.1 and 3.12.3 of BCA 2007.

${ }^{21}$ See Parts J3.2 and 3.12.3.1 of BCA 2007.

${ }^{22}$ See Parts J3.3 and 3.12.3.2 of BCA 2007.

${ }^{23}$ See Parts J3.4 and 3.12.3.3 of BCA 2007.

${ }^{24}$ See Parts J3.5 and J3.12.3.4 of BCA 2007.

${ }^{25}$ See Parts J3.6 and J3.12.3.5 of BCA 2007.
} 
Evaporative coolers (or air coolers) in cool and cold climates generally must have a selfclosing damper.

\subsection{Air Movement ${ }^{26}$}

The BCA contains provisions for air movement. The provisions apply to habitable rooms in multi-family buildings, dwellings in commercial buildings and residential houses (Table 10).

Table 10 Air Movement in Volume One and Volume Two

\begin{tabular}{|l|l|l|}
\hline $\begin{array}{c}\text { Dwelling-oriented Buildings } \\
\text { (Volume One) }\end{array}$ & \multicolumn{1}{|c|}{$\begin{array}{c}\text { Residential Houses } \\
\text { (Volume Two) }\end{array}$} & \multicolumn{1}{|c|}{ Description } \\
\hline Prescriptive provisions & N.A. & N.A. \\
\hline Application of part & Application & $\begin{array}{l}\text { Applicable building } \\
\text { classes }\end{array}$ \\
\hline Air movement & Air movement & $\begin{array}{l}\text { Minimum requirements } \\
\text { for total ventilation } \\
\text { openings per room }\end{array}$ \\
\hline Ventilation openings & Ventilation openings \\
\hline $\begin{array}{l}\text { Ceiling fans and evaporative } \\
\text { coolers }\end{array}$ & $\begin{array}{l}\text { Ceiling fans and evaporative } \\
\text { coolers }\end{array}$ & \\
\hline
\end{tabular}

The provisions relate to the number of ventilation openings per room (or the percentage of floor area of each habitable room), the installation of a ceiling fan or evaporative cooler. The requirements vary by climate zone. Ventilation requirements are highest in areas with very humid summers and warm winters (zone 1). These requirements may be met through an opening from an adjoining room under certain conditions ${ }^{27}$

In areas with warm to hot climates (zones 1 to 5), the ventilation openings must be connected by a breeze path, or by a minimum of two ventilation openings per habitable room, with each ventilation opening having an area no less than $25 \%$ of the required total ventilation opening area. ${ }^{28}$ These requirements are in addition to the requirements on total ventilation openings.

\subsection{Air-Conditioning and Ventilation Systems ${ }^{29}$}

In contrast to the previous parts (including building envelope and air movement) that focused on the physical building structure related to energy efficiency, this part emphasizes the energy efficiency of mechanical systems. Though Volume Two on residential houses does not address the performance of HVAC systems, it does address piping and ductwork insulation. ${ }^{30}$

For air-conditioning units or systems in buildings, the BCA requires that any supply and return ductwork be insulated and sealed in accordance with Specification J5.2 Ductwork

\footnotetext{
${ }^{26}$ See Part J4 in Volume One of BCA 2007 for commercial buildings, and Part 3.12.4 of Volume Two of BCA 2007 for residential houses.

${ }^{27}$ See Parts J4.2 and 3.12.4.1 of BCA 2007.

${ }^{28}$ See Parts J4.3 and 3.12.4.2 of BCA 2007.

${ }^{29}$ See Part J5 of Volume One of BCA 2007 for commercial buildings.

${ }^{30}$ See Part 3.12.5 of BCA 2007.
} 
Insulation and Sealing. When serving more than one sole-occupancy unit, airconditioning zone or area with different heating and cooling needs, ventilation systems must have the ability to thermostatically control the temperature of each sole-occupancy unit (zone or area) and limit reheating to no more than a $7.5 \mathrm{~K}$ rise in temperature. ${ }^{31}$

Mechanical ventilation systems must have efficient fan motors. When serving conditioned spaces, the system must not provide more than $50 \%$ of the minimum mechanical ventilation: in other words, designers should limit the size of ventilation systems based on need. This does not apply when buildings can draw on unconditioned outside air to provide free cooling or when the system would require additional exhaust ventilation to balance the required mechanical ventilation. ${ }^{32}$

Buildings must have time switches in accordance with Specification J6 Lighting and Power Control Devices to control air-conditioning systems of more than $10 \mathrm{kWr}^{33}$, ventilation systems with an air flow rate of more than 1,000 liters/second or heating systems of more than $10 \mathrm{~kW}_{\text {heating. }}{ }^{34}$

All piping, vessels, heat exchangers, or tanks with heated or chilled liquids must have insulation in accordance with Specification J5.4 Insulation of Piping, Vessels, Heat Exchangers and Tanks. If the system contains more than one water heater, the system should be capable of stopping the flow of water to those not operating. The related components and equipments must meet other energy efficiency requirements in the BCA as well. ${ }^{35}$

Large kitchen and bathroom exhaust systems that have variable demand, such as in a commercial kitchen, must have a variable speed fan or other means of stopping the motor when the system does not need it. The code defines large as systems with an air flow rate of more than 1,000 liters/second. ${ }^{36}$

Although Part J5 mainly concentrates on the energy efficiency of air-conditioning and ventilation systems, this part makes it clear that safety always has precedence. For example, the efficiency-related provisions for air-conditioning and ventilation systems must not inhibit the ability of these systems to ventilate smoke. These systems must maintain air flow for safe operation.

\subsection{Artificial Lighting and Power ${ }^{37}$}

This section provides prescriptive requirements for maximum lamp power density for different building types and maximum illumination power density for different building spaces. Only buildings have requirements regarding lighting. Residential houses do not

${ }^{31}$ See Part J5.2a of BCA 2007.

${ }^{32}$ See Part J5.2b of BCA 2007.

${ }^{33} \mathrm{kWr}$ refers to $\mathrm{kW}$ for air-conditioning systems.

${ }^{34}$ See Part J5.3 of BCA 2007.

${ }^{35}$ See Part 5.4 of BCA 2007.

${ }^{36}$ See Part J5.5 of BCA 2007.

${ }^{37}$ See Part J6 of Volume One of BCA 2007 for commercial buildings. 
have such provisions, and the BCA's prescriptive provisions also do not apply to soleoccupancy units in multi-family building or dwelling units in commercial buildings.

Lamp power densities are higher in commonly used spaces, such as eating areas and libraries, and lower in corridors and stairways. For example, in dwelling-oriented buildings, the maximum illumination power density ranges from $3 \mathrm{watts} / \mathrm{m}^{2}$ (in public corridors) to 25 watts $/ \mathrm{m}^{2}$ (in employee work areas). ${ }^{38}$ There are also adjustment factors for motion detectors, daylight sensors and dimmers. Time switches or sensing devices are required in most buildings with more than 250 square meters in floor space.

There are also requirements for display lighting and lighting around the perimeter of a building. Daylight sensors or time switches must control the artificial lighting around the perimeters of buildings. When total perimeter lighting load exceeds 100 watts, the lighting must have an average light source efficiency of no less than 60 lumens/watt, or be controlled by a motion detector. ${ }^{39}$

Note that the above provisions do not apply to emergency lighting, exit signs and warning systems, or to lighting within and around a detention center.

Regarding other power requirements, time switches must control the power supply to boiling or chilled water storage units. ${ }^{40}$

\subsection{Hot Water Supply ${ }^{41}$}

In buildings, hot water supply system for food preparation and sanitary purposes, must comply with a separate standard, AS/NZS 3500.4. ${ }^{42}$ The only exception to this is for solar hot water supply systems in the warmest climate zones (zones 1, 2 and 3). This provision also applies to hot water systems in residential houses. ${ }^{43}$

In residential houses, the thermal insulation on central heating water piping, and heating and cooling ductwork must have protection against the effect of weather and sunlight, and be able to withstand the temperature within the piping or ductwork. ${ }^{44}$ Central heating water piping, which is not located in a conditioned space, must be thermally insulated to achieve fixed minimum R-values, ranging from 0.2 (such as on internal piping in zone 1) to 0.6 (such as on piping located outside the building in zone 8). Heating and cooling ductwork and fittings must be sealed against air loss, and achieve set minimum total Rvalues by climate zone, ranging from 0.4 (for fittings across all zones) to 1.5 (for heatingonly systems or refrigerated cooling-only systems in zone 8$){ }^{45}$

\footnotetext{
${ }^{38}$ See Part J6.2 of BCA 2007.

${ }^{39}$ See Part J6.5 of BCA 2007.

${ }^{40}$ See Part J6.6 of BCA 2007.

${ }^{41}$ See Part J7 in Volume One of BCA 2007 for commercial buildings, and Part 3.12.5 in Volume Two of BCA 2007 for residential houses.

${ }^{42}$ See Part J7.2 of BCA 2007.

${ }^{43}$ See Part 3.12.5.0 of BCA 2007.

${ }^{44}$ See Part 3.12.5.1 of BCA 2007.

${ }^{45}$ See Part 3.12.5.2 of BCA 2007.
} 


\subsection{Access for Maintenance $^{46}$}

The BCA ensures that maintenance workers have access to all equipment and components buildings. ${ }^{47}$

Volume Two for residential houses does not address this issue.

\subsection{Energy Efficiency Installations ${ }^{48}$}

The objective of Part I2 of Section I Maintenance is "to reduce greenhouse gas emissions by efficiently using energy throughout the life of the building." It does not apply to a sole-occupancy unit in a multi-family residential building, or a dwelling part in a commercial building. A building's services (including adjustable or motorized shading devices, time switches and motion detectors, room temperature thermostats, heat transfer equipment, and others) "are to be continually capable of using energy efficiently" and meet the required energy efficiency standard continually.

Volume Two for residential houses does not address this issue.

\section{Other Developments}

\subsection{National Australian Built Environment Rating System (NABERS)}

NABERS (National Australian Built Environment Rating System) is a national initiative and was originally referred to as the Australian Building Greenhouse Rating (AGBR) scheme. AGBR was developed by the Australian Department of the Environment, Water, Heritage and the Arts (DEWHA, formerly the Department of Environment and Heritage). The New South Wales Department of Environment and Climate Change has contracted with DEWHA to promote NABERS at national level since 2005 (IEA, 2008a).

NABERS is a performance-based rating system that measures overall environmental performance of an existing building during operation. The building types include commercial offices, hotels or residential buildings. The measured environmental performance include energy, refrigerants (greenhouse and ozone depletion potential), water, stormwater runoff and pollution, sewage, landscape diversity, transport, indoor air quality, occupant satisfaction, waste, and toxic materials (NABERS, 2008).

Property owners, occupants, investors and other stakeholders can use NABERS to assess the environmental impacts of building use, and to define and set operational performance targets and measure actual performance. It can be done either with NABERS selfassessment tools, or with a NABERS certified assessor who can issue a certified rating. The issued certified rating can then be displayed and publicized (IEA, 2008a).

For more information, please refer to www.nabers.com.au.

\footnotetext{
${ }^{46}$ See Part J8 in Volume One of BCA 2007 for commercial buildings.

${ }^{47}$ See Part J8.1 of BCA 2007.

${ }^{48}$ See Part I2 in Volume One of BCA 2007 for commercial buildings.
} 


\subsection{Nationwide House Energy Rating Scheme (NatHERS)}

The Nationwide House Energy Rating Scheme (NatHERS) helps Australian households assess how energy efficient their homes are. The goal of this government-initiated program is to help homeowners make more informed choices about home purchases and renovations (NaHERS, 2008).

NatHERS provides a framework for accrediting various computer software tools to rate the potential thermal comfort of Australian homes. To gain accreditation, software tools are required to assess the same minimum set of design features, and must produce a consistent rating. NatHERS accredited software provides a rating on a scale of zero to 10 stars. The more stars, the less likely the occupants need cooling or heating to stay comfortable.

Achieving a certain star rating meets most of the energy efficiency requirements within the BCA for the building envelope. The star rating target is five stars but varies slightly between jurisdictions and is currently lower for apartments than for houses. An alternative to star rating is to construct the dwelling using methods described in the Deemed-to-Satisfy Provisions of the BCA. The Australian Capital Territory Government also requires the disclosure of the NatHERS rating prior to the sale or lease of each house (IEA, 2008b).

For more information, please refer to www.nathers.gov.au/about/index.html.

\subsection{Green Loans Program for Households}

The Australian Government announced the Green Loans program in May 2008, a fiveyear program working to help Australian households install solar, water saving, and energy efficient products. The Green Loans Program will provide: (1) access to detailed, quality household sustainability assessments, (2) green renovations packs (CFLs, low flow showerhead, shower timers), and (3) access to low interest Green Loans of up to AUS $\$ 10,000$ each.

For more information, please refer to www.environment.gov.au/greenloans/index.html.

\subsection{Voluntary Building Industry Initiatives}

In 2006, the Australian Government introduced the Voluntary Building Industry Initiatives Programme, aimed to persuade the building industry to adopt best practices to reduce greenhouse gas impacts from building and construction operations (DEWHA, 2008). Projects developed include the:

- Window Energy Rating Scheme,

- Environmental Design Guides,

- Marketing Sustainable Design Workshops (under the Building Developers' Association of America),

- Greensmart Professional Accreditation Course (under the Housing Industry Association), 
- Energy Wise-Dollar Wise Training Course and

- Lighting Best Practice Project.

For more information on, please refer to www.environment.gov.au/settlements/energyefficiency/buildings/practices.html.

\subsection{Energy Efficiency Homes Package}

In early 2009, the Australian government announced a new program to help improve energy efficiency in homes. The program offers ceiling insulation worth up to AU $\$ 1,600$ to all Australian owner-occupiers of currently uninsulated homes, an AUS\$1,600 rebate on the cost of installing solar hot water systems and rebates for landlords on the costs of insulating rental properties. These benefits are available to all Australians, regardless of income. The goal of the program is to help residents save up to $40 \%$ on their electricity bills. Currently, the government estimates that $40 \%$ of Australians homes are not insulated.

For more information, please see www.environment.gov.au/energyefficiency/index.html.

\section{Conclusions}

Energy efficiency measures were introduced into the BCA, a national building code system, in January 2003. The integration of the BCA helps effectively promote energy efficiency in new buildings and simplifies the energy efficiency requirements across jurisdictions in Australia. The Australian government, research institutes, NGOs, and building associations have been and are highly active in conducting research and outreach activities to improve implementation of the building energy codes. Australia clearly has emerged as a leading country in the promotion of building energy efficiency. 


\section{List of Acronyms}

$\begin{array}{ll}\text { ABCB } & \text { Australian Building Codes Board } \\ \text { APP } & \text { Asia-Pacific Partnership on Clean Development and Climate } \\ \text { AS } & \text { Australian standards } \\ \text { AS/NZS } & \text { Australian-New Zealand standards } \\ \text { BCA } & \text { Building Code of Australia } \\ \text { BCA 2007 } & \text { The 2007 version of BCA } \\ \text { BCA 2009 } & \text { The 2009 version of BCA } \\ \text { DEWHA } & \text { Department of Environment, Water, Heritage and the Arts } \\ \text { GDP } & \text { Gross domestic product } \\ \text { HVAC } & \text { Heating, ventilation and air conditioning } \\ \text { MEPS } & \text { Minimum Energy Performance Standards } \\ \text { NABERS } & \text { National Australian Built Environment Rating System } \\ \text { NatHERS } & \text { Nationwide House Energy Rating Scheme } \\ \text { NFEE } & \text { National Framework for Energy Efficiency } \\ \text { NGO } & \text { Non-governmental organization } \\ \text { OECD } & \text { Organisation for Economic Co-operation and Development } \\ \text { R\&D } & \text { Research and development }\end{array}$




\section{References}

1. ABCB, 2008a. Australia Building Codes Board: Energy Efficiency General Information, http://www.abcb.gov.au/go/whatweredoing/workprogram/projectsae/energy/eegenera 1, October 2008, (Accessed).

2. ABCB, 2008b. Australian Building Codes Board - About the ABCD, http://www.abcb.gov.au/go/about-abcb/about, January 2009, (Accessed).

3. ABCB, 2008c. BCA 2009 Climate Zone Map - Australia, http://www.abcb.gov.au/index.cfm?objectid=8F430911-F5F2-F0543EA8CA580F14414A, January 2009, (Accessed).

4. ABCB, 2008d. Hierarchy of the Performance-based BCA, https://www.abcb.gov.au/go/about_bca_p2, January 2009, (Accessed).

5. Australia Institute of Building, 2008. Set the BCA Free, http://www.bca4free.com.au/mainpage.htm, January 2009, (Accessed).

6. Australian Government, 2004. Securing Australia's Energy Future, http://www.efa.com.au/Library/CthEnergyWhitePaper.pdf, January 2009, (Accessed).

7. Australian Institute of Building, 2004. BCA - Building Code of Australia, http://www.aib.org.au/buildingcodes/bca.htm, January 2009, (Accessed).

8. DEWHA, 2008. Voluntary Building Industry Initiatives, http://www.environment.gov.au/settlements/energyefficiency/buildings/practices.html, December 2008, (Accessed).

9. EIA, 2008. World Carbon Dioxide Emissions from the Consumption and Flaring of Fossil Fuels, www.eia.doe.gov/emeu/international/carbondioxide.html, January 2009, (Accessed).

10. IEA, 2005. Energy Policies of IEA Countries - Australia (2005 Review). International Energy Agency.

11. IEA, 2007. Energy Balances of OECD Countries (2007 edition). OECD, Paris.

12. IEA, 2008a. The National Australian Built Environment Rating System, http://www.iea.org/textbase/pm/?mode=pm\&id=4165\&action=detail, December 2008, (Accessed).

13. IEA, 2008b. Performance Standards and 5-Star Rating for Buildings: MEPS and NatHERs, http://www.iea.org/textbase/pm/?mode=pm\&id=2607\&action=detail, December 2008, (Accessed).

14. IMF, 2008a. World Economic Outlook Database, January 2009, (Accessed).

15. IMF, 2008b. World Economic Outlook Databases, www.imf.org/external/ns/cs.aspx?id=2, January 2009, (Accessed).

16. McGlynn, G., 2006. Incorporating Energy Performance Requirements into Building Codes Across Many Climate Zones: Australia's Experience

17. http://www.iea.org/textbase/work/2006/buildings/mcglynne.pdf, September 2008, (Accessed).

18. NABERS, 2008. NABERS, http://www.nabers.com.au/, December 2008, (Accessed).

19. NaHERS, 2008. Nationalwide House Energy Rating Scheme, http://www.nathers.gov.au/about/index.html, December 2008, (Accessed).

20. NFEE, 2008. NFEE Stage One, http://www.nfee.gov.au/about_nfee.jsp?xcid=66, December 2008, (Accessed). 


\section{Useful Websites}

1. Australian Building Codes Board, www.abcb.gov.au

2. Australia Department of Climate Change, www.climatechange.gov.au

3. Department of the Environment, Water, Heritage and the Arts, www.environment.gov.au

4. National Australian Built Environment Rating System, www.nabers.com.au

5. National Framework for Energy Efficiency, www.nfee.gov.au 


\section{The Asia-Pacific Partnership on Clean Development and Climate}

The Asia-Pacific Partnership on Clean Development and Climate is an innovative new effort to accelerate the development and deployment of clean energy technologies.

\section{Partner Countries}

APP partners Australia, Canada, China, India, Japan, Republic of Korea, and the United States have agreed to work together and with private sector partners to meet goals for energy security, national air pollution reduction, and climate change in ways that promote sustainable economic growth and poverty reduction. The Partnership will focus on expanding investment and trade in cleaner energy technologies, goods and services in key market sectors. The Partners have approved eight public-private sector task forces covering:

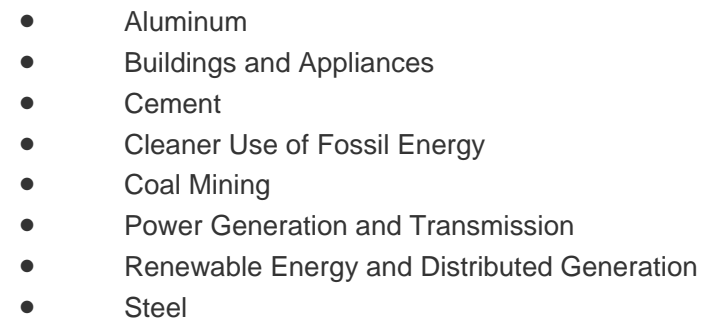

The seven partner countries collectively account for more than half of the world's economy, population and energy use, and they produce about 65 percent of the world's coal, 62 percent of the world's cement, 52 percent of world's aluminum, and more than 60 percent of the world's steel.

\section{Buildings and Appliances Task Force}

Reducing our use of energy for buildings and appliances decreases the demand for primary energy and is a key means to deliver better economic performance, increase energy security and reduce greenhouse gas and air pollutant emissions. Partner countries have recognized for some time the importance of cooperating on energy efficiency for buildings and appliances, and have already taken a range of bilateral and other collaborative actions in this area. As the Partners represent a majority of the world's manufacturing capacity for a diverse range of appliances, we have the potential to drive significant regional and global improvements in energy efficiency in this sector. The Partners will demonstrate technologies, enhance and exchange skills relating to energy efficiency auditing, share experiences and policies on best practices with regard to standards and codes, as well as labeling schemes for buildings, building materials and appliances. 


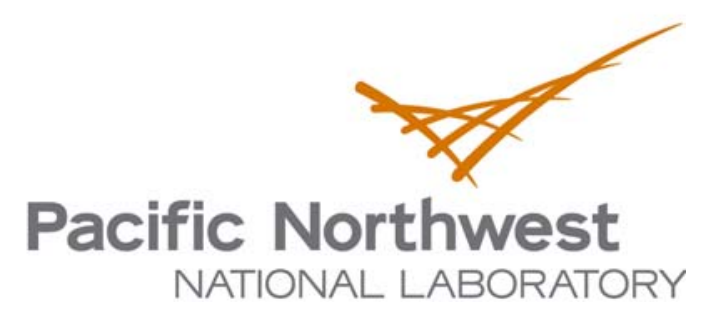

